\section{Mercury pollution in Brazil}

SIR - Gold mining in the Brazilian Amazon involves more than 650,000 people and results in the annual discharge of 90-120 tonnes of mercury into local ecosystems ${ }^{1,2}$. Miners extend the gold rush each year to other rivers and the release of mercury into the environment of the region continues to rise. For more than ten years, the Madeira River basin has been the centre of the gold rush in Brazil and has yielded more than 100 tonnes of gold so far $^{1,2}$. We present probably the first accurate concentrations of mercury in the Madeira River (see table), and demonstrate that the bioaccumulation of pollutant mercury in many fish species has resulted in levels considered unsafe for human consumption. Many miners and some local residents may already be poisoned by mercury ${ }^{3}$, but the effects of the ongoing buildup of mercury in local food chains may become more severe on wildlife, especially piscivorous mammals.

Our study was conducted in the State of Rondonia, between the towns of Porto Velho and Guajara Mirim near the Bolivian border. Surface-water samples were collected in properly decontaminated polyethylene bottles using scrupulous methods in the field to exclude sample contamination. Determination of $\mathrm{Hg}$ in the samples was made by cold vapour atomic absorption spectrometry (CVAAS) in an ultra-clean laboratory equipped with gold-coated air filters ${ }^{4}$. Edible portions of many fish species from the local waters were also analysed by CVAAS. The dissolved and particulate $\mathrm{Hg}$ concentrations in the Madeira River and its tributary average $13.8 \pm 2.5$ and $10.8 \pm 4.4 \mathrm{ng} \mathrm{l}^{-1}$, respectively (see table). The particulate form of $\mathrm{Hg}$ thus constitutes about $44 \%$ of the mean total $\mathrm{Hg}$ concentration of $24.6 \pm 4.5 \mathrm{ng} \mathrm{l}^{-1}$. These results are many times lower than the previously reported $\mathrm{Hg}$ concentrations in the Madeira River which range tal Protection Agency? of the mining areas.

from $<40$ to $>9,000 \mathrm{ng} \mathrm{l}^{-1}$ (see ref. 3 ). By comparison, the dissolved $\mathrm{Hg}$ concentrations in unpolluted lakes and rivers are generally $<3 \mathrm{ng}^{-1}$ (ref. 5). The average value for Madeira River is about 17 -fold higher than the $0.82 \mathrm{ng} \mathrm{l}^{-1}$ estimated to be the mean dissolved $\mathrm{Hg}$ concentration in the rivers of the world ${ }^{6}$, and the total $\mathrm{Hg}$ concentrations are higher than the 4-day ambient water quality standard of $12 \mathrm{ng} \mathrm{l}^{-1}$ that has been established by the US Environmen-

The estimated total release of $\mathrm{Hg}$ in the Madeira River basin is about $32 \mathrm{t}$ $\mathrm{yr}^{-1}$ (refs 1,2 ). From the average flow rate $\left(920 \times 10^{12} 1 \mathrm{yr}^{-1}\right)$ and total $\mathrm{Hg}$ concentration, the transport of $\mathrm{Hg}$ by the Madeira River is estimated to be $23 \mathrm{t}$ $\mathrm{yr}^{-1}$, implying that most of the pollutant $\mathrm{Hg}$ is exported to the Amazon River, thereby extending the region of influence of the mining operation. About $28 \%$ of the $\mathrm{Hg}$ pollution is stored locally in the river basin, mostly in the sediments, aquatic biota, soils and vegetation. Indeed, the $\mathrm{Hg}$ content of some stream sediments exceeds $150 \mu \mathrm{g} \mathrm{g}^{-1}$ (ref. 3), and puddles of $\mathrm{Hg}$ are common on soils and rock surfaces at the shores

The severity of $\mathrm{Hg}$ contamination is well documented by the following elevated $\mathrm{Hg}$ levels in fish from Madeira River and its tributaries: 1.01 \pm 0.64 , $0.13 \pm 0.08$ and $0.12 \pm 0.06 \mu \mathrm{g} \mathrm{g} \mathrm{g}^{-1}$ for carnivorous, omnivorous and detritusfeeding species, respectively ${ }^{3}$. The $\mathrm{Hg}$ contents of most of the carnivorous and some of the omnivorous species exceed the limits $\left(<0.5 \mu \mathrm{g} \mathrm{g}^{-1}\right)$ for $\mathrm{Hg}$ in edible fish tissues that have been established in many countries ${ }^{8}$. The Madeira is a productive river and a major source of fish for local populations in its drainage basin $^{1,2}$. The consumption of $10-20 \mathrm{~g}$ of the carnivorous fish on a regular basis by a $20-\mathrm{kg}$ child can easily result in mercury

MERCURY CONCENTRATIONS (NG L ${ }^{-1}$ ) IN MADEIRA RIVER WATER AND ITS TRIBUTARIES

Sample location

Dissolved

Particulate

Total

Mutum Parana (junction with Madeira River) Mutum Parana (30 $\mathrm{m}$ from highway)

Prainha

Humaita, mid-river

Humaita, nearshore

Porto Velho

Cachoeira Teotonio (a fishing village)

$2 \mathrm{~km}$ above Teotonio Falls

$4 \mathrm{~km}$ above Teotonio Falls

$8 \mathrm{~km}$ above Teotonio Falls

$10 \mathrm{~km}$ above Teotonio Falls

$12 \mathrm{~km}$ above Teotonio Falls

11.3
9.8
15.0
15.8
12.5
13.7
13.3
10.7
16.3
17.2
12.7
17.1

14.5

17.5

18.2

6.4

8.5

10.4

10.4
6.6

9.1

6.2

8.5

8.5
9.1
15.3

15.3

\section{8}

27.3

33.2

22.2

21.0

24.1

19.8

19.9

22.5

25.6

21.9

32.4

Average

$13.8 \pm 2.5 \quad 10.8 \pm 4.4$ poisoning considering that the World Health Organization recommended tolerable daily intake limit is only 0.43 $\mu \mathrm{g}$ per $\mathrm{kg}$ body weight ${ }^{8}$. If the child also lives near where the amalgam is burned, there is added intake of $\mathrm{Hg}$ from the atmosphere and contaminated dusts.

Although the popular news media have given extensive coverage to $\mathrm{Hg}$ pollution associated with the gold mining, scientific investigation of most aspects of the problem has been very limited. The environmental costs of the contamination of the Amazon with mercury could be enormous.

JeROME O. NRIAGU

National Water Research Institute,

Box 5050, Burlington,

Ontario L7R 4A6, Canada

Wolfgang C. Pfeiffer

OLAF MALM

Cristina M. MagalhaES de SOUZa

Instituto de Biofisica Carlos Chagas

Filho,

Universidade Federal do Rio de Janeiro, RJ 21941, Brazil

Ontario Ministry of the Environment,

GREGORY MIERLE

Dorset Research Centre,

PO Box 39, Dorset,

Ontario POA 1EO, Canada

1. Pfeiffer, W. C. \& Lacerda, L. D. Envir. Techn. Lett. 9 325-330 (1988)

. Malm, O.. Pfeiffer, W. C., Souza, C. M. M. \& Reuther R. AMBIO 19, 11-15 (1990)

3. Malm, 0 . thesis. (Federal University of Rio de Janeiro, Brazil, 1991).

4. Mierle, G. Envir. Toxic. Chem. 9, 843-851 (1990)

5. Giil, G. A. \& Bruland, K. W. Envir. Sci. Techn. 24, 1392-1400 (1990).

6. Nriagu, J. O. in Proc. Symp. Trace Metals (USDA Forest Service, North Central Forest Experiment Station, St Pauls, Minnesota, in the press).

7. EPA Ambient Water Quality Criteria for Mercury Report No. EPA-440/5-84-026 (Criteria and Standards Division, US EPA, Washington, DC, 1985).

8. WHO Environmentai Health Criteria 101: Methylmercury (World Health Organisation, Geneva, 1990)

\section{Human origins}

SIR - The superb sets of human mitochondrial tree data collected by Cann et al. ${ }^{1}$ and Vigilant et al. ${ }^{2}$ have turned out to be remarkably difficult to analyse in a way that can yield a consistent story about human origins. The possibility that the data show an African mitochondrial 'Eve' has recently been questioned in the light of the discovery that the apparent exclusively African branch is not as clearly separated from the rest of the tree as had originally been suggested ${ }^{3-6}$.

The ways in which these and many other phylogenetic trees are usually presented pictorially may encourage inadvertent overinterpretation of the data $^{7}$. The reasons are twofold. First, trees are usually drawn with time on the $x$-axis, so that the branches of the trees are arranged horizontally. Sometimes a procrustean approach is used to lengthen or shorten the branches arbitrarily and 